\title{
Role of several histone lysine methyltransferases in tumor development (Review)
}

\author{
JIFU LI ${ }^{1}$, SHUNQIN ZHU $^{2}$, XIAO-XUE KE ${ }^{1}$ and HONGJUAN CUI ${ }^{1}$ \\ ${ }^{1}$ Cell Biology Laboratory, State Key Laboratory of Silkworm Genome Biology, ${ }^{2}$ School of Life Science, \\ Southwest University, Chongqing 400716, P.R. China
}

Received July 20, 2015; Accepted December 31, 2015

DOI: $10.3892 /$ br.2016.574

\begin{abstract}
The field of cancer epigenetics has been evolving rapidly in recent decades. Epigenetic mechanisms include DNA methylation, histone modifications and microRNAs. Histone modifications are important markers of function and chromatin state. Aberrant histone methylation frequently occurs in tumor development and progression. Multiple studies have identified that histone lysine methyltransferases regulate gene transcription through the methylation of histone, which affects cell proliferation and differentiation, cell migration and invasion, and other biological characteristics. Histones have variant lysine sites for different levels of methylation, catalyzed by different lysine methyltransferases, which have numerous effects on human cancers. The present review focused on the most recent advances, described the key function sites of histone lysine methyltransferases, integrated significant quantities of data to introduce several compelling histone lysine methyltransferases in various types of human cancers, summarized their role in tumor development and discussed their potential mechanisms of action.
\end{abstract}

\section{Contents}

1. Introduction

2. Histone lysine methyltransferases

3. Conclusion

Correspondence to: Professor Hongjuan Cui, Cell Biology Laboratory, State Key Laboratory of Silkworm Genome Biology, Southwest University, 2 Tiansheng Road, Chongqing 400716, P.R. China

E-mail: hcui@swu.edu.cn; hongjuan.cui@gmail.com

Key words: histone lysine methyltransferases, histone methylation, tumor development

\section{Introduction}

Tumor initiation and progression were traditionally described as a consequence of genetic variations; breakthroughs in epigenetic mechanisms provided more evidence to show that epigenetic changes have critical roles in tumor development. Targeting epigenetics appears to be a promising therapy for cancer treatment. Several targeting epigenetic drugs for cancer patients have already obtained approval by the Food and Drug Administration (1).

As epigenetic markers, post-translational modification of histone, involving methylation, acetylation, phosphorylation as well as ubiquitination, SUMOylation, adenosine diphosphateribosylation, deimination and proline isomerization, are critical determinants for tumor initiation and progression, which could be passed to daughter cells. A number of previous studies have demonstrated that histone modifications are important for the recruitment or activity of downstream effectors. As aberrant histone modifications are associated with divergent reactions, the present review focuses on histone methylation. Histone methylation was first described in 1964 by Murray (2), and frequently occurs at lysine and arginine residues at the $\mathrm{N}$-terminals of $\mathrm{H} 3$ and $\mathrm{H} 4$. Histone methylation can engage in either gene activation or silencing depending on specific sites, which may result in the promotion of tumor development (3-5). The lysine residues can be either mono-, di- or tri-methylated, and only the arginine residues can be mono- or di-methylated, and this can have divergent effects on gene transcription (6-9).

As essential tools to ensure accomplished methylation, histone methyltransferases (HMTs) transfer methyl groups from S-adenosyl methionine to the lysine and arginine residues, which further affect gene transcription, chromatin compaction and effector proteins binding $(8,10,11)$. To date, histone methyltransferases has received much attention (Fig. 1), and $\sim 47 \%$ of previous studies regarding HMTs were associated with tumor development. Currently, 51 SET domain lysine HMTs, 1 non-SET domain lysine HMT (DOT1L) and 9 arginine HMTs have been identified, and the majority of these are associated with cancer development (11). Misregulation of HMTs shifts the balance of transcription and leads to changes in cell fate, resulting in tumor formation. The following are summaries of the current knowledge of certain histone lysine methyltransferases (HKMTs) and their key sites, whilst exploring the relevance of HMTs and cancer development. 


\section{Histone lysine methyltransferases}

The HKMT family contains an evolutionarily conserved SET domain, which is defined as a 130 -amino acid sequence carrying the two most-conserved sequence motifs ELXF/YDY and NHS/CXXPN. It catalyzes the site- and state-specific methylation of different lysine residues with relatively high substrate specificities. There have been 52 family members identified, including 51 SET domain lysine HMTs and 1 non-SET domain lysine HMT, known as DOT1L (12).

Studies have verified that histone lysines 4, 9, 27, 36 and 79 of histone H3 (H3K4, H3K9, H3K27, H3K36 and H3K79), and 20 of histone H4 (H4K20) may be methylated (Fig. 2). Methylation can take three forms: Mono-(me1), di-(me2) and tri-(me3) methylation. Each histone methylation has a function in regulating transcription and chromatin conformation. H3K4me2/3, H3K9me1, H3K27me1, H3K36me3, H3K79me3 and H4K20me1 are generally enriched in active transcribed regions, while $\mathrm{H} 3 \mathrm{~K} 9 \mathrm{me} 2 / 3, \mathrm{H} 3 \mathrm{~K} 27 \mathrm{me} 2 / 3$ and H4K20me3 are associated with gene repression (13).

H3K9 methyltransferases G9a and SETDB1. Methylation of histone H3K9 is a well-conserved epigenetic marker for transcriptional silencing (14). Histone H3K9 methylation and DNA methylation can work together on the establishment and maintenance of heterochromatin (15). The methyltransferases responsible for histone $\mathrm{H} 3 \mathrm{~K} 9$ methylation are able to catalyze different substrates and lead to various results (16). These include Clr4/SUV39H1 (17), SUV39H2 (18), G9a (19), GLP/Eu-HMTase1 (20),ESET/SETDB1 (21),Riz1/PRDM2 (22) and CLLD8/KMT1F (23).

Among these HKMTs, G9a is critical for gene silencing and embryo development. Currently, aberrant regulation of G9a has been identified in a number of cancers (Fig. 3), and is involved in the control of cancer metabolism by maintaining the serineglycine biosynthetic pathway (24). In PC3 prostate cancer cells, knockdown of G9a significantly inhibits cell growth and induces cellular senescence, and higher G9a expression is associated with poorer prognosis in cancer patients (25). In addition, knockdown of G9a promotes E-cadherin expression in claudin-low breast cancer (CLBC), and inhibited cell migration and invasion in CLBC and lung cancer $(26,27)$. In ovarian cancer, higher G9a expression predicts a greater mortality of patients (28). In neuroblastoma, our previous study reported the importance of G9a in regulating the autophagy signaling pathway, knockdown of G9a inhibited cell growth and proliferation, and the activation of autophagy occurred (29). In acute myeloid squamous cell carcinoma and pancreatic adenocarcinoma, inhibition of G9a induced autophagy-related cell death $(30,31)$. In glioma cancer, previous studies have identified that G9a-dependent H3K9me2 repressed cluster of differentiation 133 and Sox 2 expression and in leukemia, and loss of G9a markedly delayed tumor progression and repressed ATRA-mediated leukemia cell differentiation $(32,33)$. Additionally, in head and neck cancer, G9a inhibited stem cell self-renewal (34). G9a was also upregulated in hepatocellular carcinoma (HCC) tissues, and cooperated with the $\mathrm{H} 3 \mathrm{~K} 9$ methylation effector protein CDYLb, which is involved in HCC development $(35,36)$. In oesophageal squamous cell carcinoma, G9a may serve as an effective prognostic factor and be used as a biomarker (37).
Another key enzyme is SETDB1 (Fig. 3), which has been reported in numerous types of human cancer. SETDB1 was identified in 1999, and the activity of histone H3-K9-specific methyltransferase was reported in $2002(38,39)$. SETDB1 is recruited by various transcription factors to regulate gene expression, and is associated with the $\mathrm{H} 3 \mathrm{~K} 9 \mathrm{me} 3$-enriched genome regions (40). As a constitutive member of promyelocytic leukemia-nuclear bodies, SETDB1 has been linked to numerous cellular processes, such as apoptosis, DNA damage responses and transcriptional regulation (41). In melanoma, a study in zebrafish regarded SETDB1 as an oncogene, and indicated its role in regulating tumorigenesis (42). SETDB1 was upregulated in cell lines and tissues in a number of human carcinomas, for example, non-small and small lung cancer, glioma and prostate cancer. In non-small and small lung cancer, recent studies have shown that knockdown of SETDB1 reduced lung cancer cell growth in vitro and in vivo, and overexpression of SETDB1 promoted cancer cell invasiveness (43-46). In glioma, suppression of SETDB1 by siRNA significantly reduced cell proliferation (47). In prostate cancer, downregulation of SETDB1 by siRNA inhibited PCa cell proliferation, migration and invasion (48). Another study reported that a microRNA, known as miR-7, directly targeted SETDB1, and inhibited breast cancer stem cell (CSC) invasion and metastasis, and decreased the breast CSC population, which suggested that SETDB1 activity is important in breast cancer (49).

H3K27methyltransferasezesteprotein-2(EZH2). Methylation of histone H3K27 is correlated with transcriptional repression (50). Enhancer of EZH2, as a catalytic component of the polycomb repressive complex 2, catalyzes histone $\mathrm{H} 3 \mathrm{~K} 27$ tri-methylation. To date, $>300$ studies have reported a close correlation between EZH2 and 46 types of human cancer (Fig. 4). EZH2 is commonly overexpressed in the majority of common cancers, and high EZH2 expression is a prognostic indicator of poor survival. In breast cancer, downregulation of EZH2 blocks the cell cycle, and suppresses cell growth and survival (51-54). In prostate cancer, knockdown of EZH2 inhibits cell proliferation and invasion (55-57). In glioma stem cells, EZH2 is a known target of the MELK-FOXM1 complex, having a critical role in promoting resistance to radiation (58). In glioma and clear cell renal cell carcinoma, downregulation of EZH2 expression can reduce cell proliferation and increase cell apoptosis $(59,60)$. Furthermore, in non small-cell lung cancer, EZH2 silencing alters the cell cycle by inducing $\mathrm{G}_{2} / \mathrm{M}$ arrest (61). In lymphoma, overexpression of EZH2 promotes the proliferation and aggressiveness of neoplastic cells, facilitates malignant tumor cell diffusion and mediated transcriptional silencing (62). Additionally, knockdown of EZH2 induces RUNX expression to further inhibit cell proliferation in gastric, breast, prostate, colon and pancreatic cancer cells (63). Furthermore, EZH2 is important in other types of cancer, including malignant peripheral nerve sheath tumor (64), medulloblastoma (65) and lung adenocarcinoma (66).

H3K4 methyltransferase SMYD3. Methylation of $\mathrm{H} 3 \mathrm{~K} 4$, as an epigenetic phenomenon conserved from yeast to human, is extremely important for transcriptional initiation. It recruits proteins for transactivation, and has reverse functionally to H3K9 methylation. As a common marker of activated genes, 


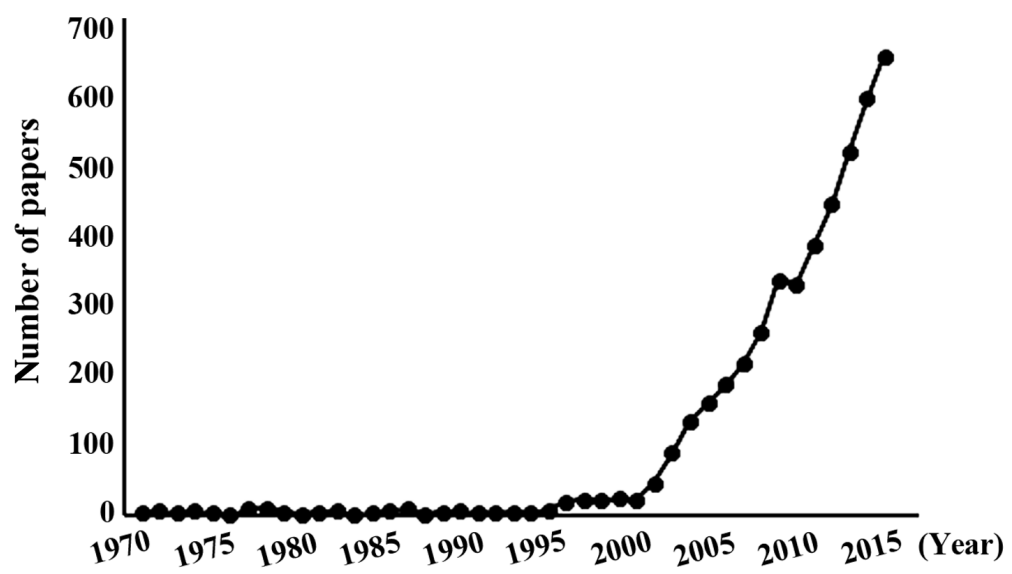

Figure 1. Published studies of histone methyltransferases associated with cancer. In the past few decades, the number of published studies of histone methyltransferases that are associated with cancer has significantly increased.

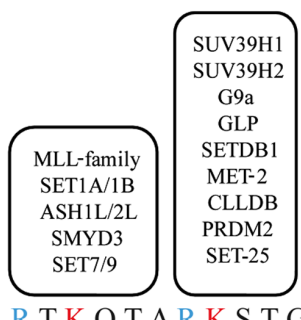

H3 A R T K Q T ARK S T
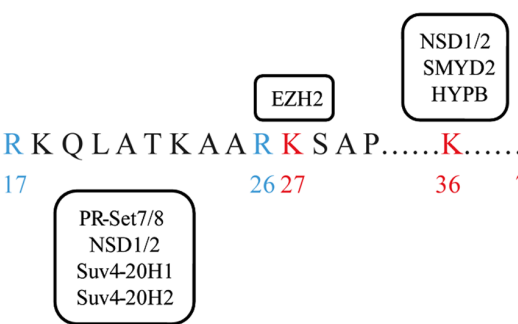

$24 \quad 8 \quad 9$

2627

........K

R K V L R D N I Q G I T

H4 S G R G K G G K G L G K G GAK R H R K

Figure 2. Function sites of histone methyltransferases. The histone methyltransferases can catalyze the methylation of histone lysine $4,9,27,36$ and 79 of histone H3 (H3K4, H3K9, H3K27, H3K36 and H3K79), and 20 of histone H4 (H4K20).

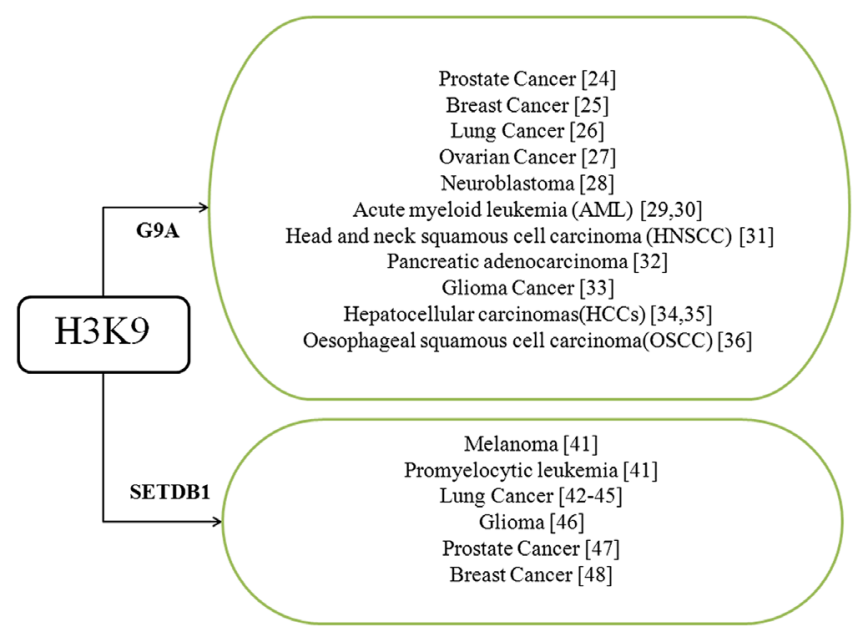

Figure 3. Types of cancer associated with H3K9-specific methyltransferases G9a and SETDB1. Two H3K9 methyltransferases, G9a and SETDB1, have been identified to have a critical role in a variety of tumors. H3K9, histone lysine 9 of histone $\mathrm{H} 3$.

$\mathrm{H} 3 \mathrm{~K} 4$ tri-methylation provides an epigenetic signature of active enhancers (67). H3K4 methyltransferases include the mixed lineage leukemia (MLL) family (68), SET1A/B (69), absent, small or homeotic disks 1-like (ASH1L) (70), ASH2L (71), SET and MYND domain-containing protein 3 (SMYD3) (72), SET7/9 (73), and SMYD1 (74). However, in mammals, $\geq 6 \mathrm{H} 3 \mathrm{~K} 4$ methyltransferases, including Set1A and Set1B and MLLs 1-4, exhibit histone methyltransferase activity (68).

As cardiac- and muscle-specific histone methyltransferases, except for the regulation of early heart development, the oncogenic role of SMYD3 has been identified in different types of cancer. In colorectal cancer, HCC and esophageal squamous cell carcinoma, knockdown of SMYD3 impairs cell proliferation (75-77). Similarly to CRC and HCC, in breast cancer, silencing of SMYD3 also inhibits cell growth, and SMYD3 promotes breast carcinogenesis by directly regulating the protooncogene WNT10B (78). In cervical carcinoma cells and prostate cancer, reduction of SMYD3 expression by doxycycline or small hairpin RNA is able to significantly inhibit cell proliferation, colony formation and migration/invasion activity $(79,80)$.

H3K36 methyltransferases. H3K 36 methylation is an indicator of transcriptional elongation, and H3K36 methyltransferases contain nuclear receptor binding SET domain-containing protein 1 (NSD1), NSD2, NSD3 (81), SMYD2 and SETD2 (82). These are involved in diverse biological processes, including 


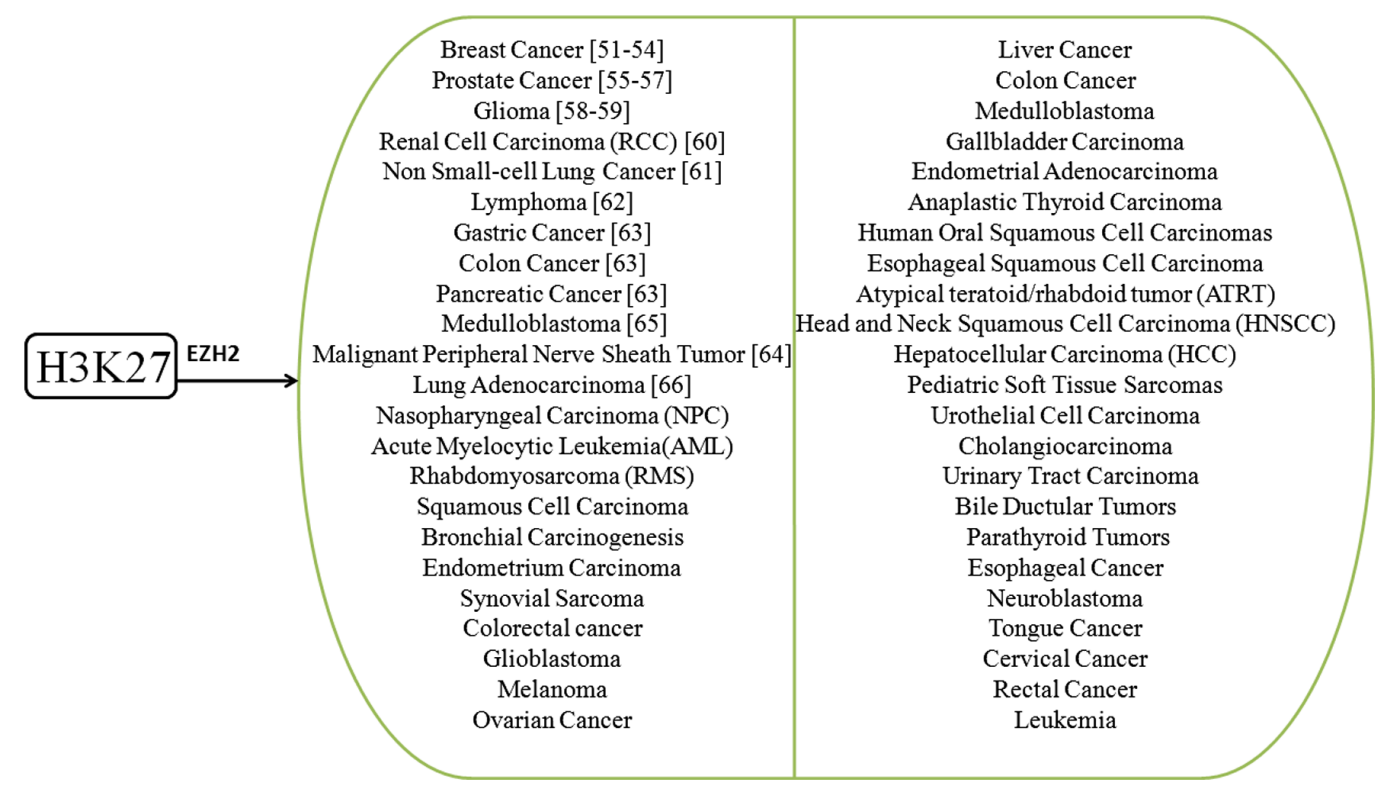

Figure 4. Types of cancer associated with H3K27-specific methyltransferase zeste protein-2 (EZH2). The H3K27 methyltransferase EZH2 is involved in 46 types of cancer. H3K27, histone lysine 27 of histone H3.

alternative splicing and transcriptional repression, as well as DNA repair and recombination (83).

The NSD family is known to be involved in multiple types of cancer, and knockdown of NSD members would suppress cell proliferation and tumor growth. NSD1 specifically mediates methyl transfer onto H3K36 and H4K20. In prostate cancer, NSD1 can enhance androgen receptor transactivation and is associated with prostate tumorigenesis $(84,85)$. In neuroblastoma, overexpression of NSD1 induces tumor suppressor-like features, such as reduced colony formation density and inhibited cell growth (86). NSD1 has been reported in numerous types of cancer, including multiple myeloma (87), acute myeloid leukemia $(88,89)$, lung cancer $(90,91)$ and ganglioglioma $(92)$. SETD2 is a novel tumor suppressor, which is responsible for H3K36me3 reduction, further resulting in tumor growth inhibition. Mutated SETD2 has been frequently identified in human leukemia, thymic carcinoma (93), renal cell carcinoma $(82,94)$, non-small cell lung cancer (95) and pediatric glioma (96).

H3K79 methyltransferases. In general, H3K79 methylation correlates with gene transcription $(97,98)$. Disrupter of telomeric silencing 1 (DOT1), the only known H3K79 methyltransferase, participates in the regulation of transcription, development, differentiation and proliferation of normal cells (99). However, the role of DOT1L in cancer cells remains to be elucidated. Dot1 has been shown to interact with multiple MLL fusion partners including AF9, 11-19-leukemia protein, AF10 and AF17. In clinically aggressive acute leukemia, it may be involved in cell survival pathways, and loss of Dot1 activity attenuates cell viability and the colony formation ability (100). However, in lung cancer, downregulation of DOT1L reduces cell proliferation and led to cell cycle arrest at the $\mathrm{G}_{1}$ phase (101).

H4K20 methyltransferases. Methylation of H4K20 has been implicated in multiple biological processes, such as gene transcriptional regulation, cell cycle control, development and genomic integrity maintenance $(102,103)$. Mono- and di-methylated H4K20 have been attributed to DNA replication, DNA damage repair and chromatin compaction. Lack of H4K20me1 results in chromosome condensation in the interphase nucleus. Tri-methylation of H4K20 is required for silencing heterochromatic regions (104).

H4K20 methyltransferases include SUV4-20H1 and SUV4-20H2 (104), PR-Set7/Set8/KMT5A (105), NSD1 (106) and NSD2/WHSC1/MMSET (107). SUV4-20H1 and SUV4-20H2 mediate H4K20me2 and H4K20me3, NSD2 mediates methyl transfer onto H3K4 and H4K20, and PR-Set7 is known as the sole enzyme that catalyzes H4K20mel (108). In breast cancer cells, overexpression of SUV420H1 and SUV420H2 suppresses cell invasiveness, whereas knockdown of SUV420H2 activates normal mammary epithelial-cell invasion in vitro (109).

\section{Conclusion}

HMTs have become more important in epigenetics and cancer in recent years. There appear to be numerous connections between SET-domain proteins and cancer. HKMTs are important in regulating gene transcription, which may lead to various human malignancies. Among these key sites, H3K9 and H3K27 occupy the majority of the active proteins. Although the functions of HMTs have been explored extensively, the downstream and pathological mechanisms remain to be elucidated.

The present review summarizes the current understanding of HMTs, provides a platform for exploring potential therapy targets through histone modifications, and provides insights into a potential role of aberrant histone modifications in various human malignancies. The aforementioned methylation accumulated the complexity of histone modifications, which provides new insights of these functions in different patterns and their involvement in additional diseases. 
Previous studies have provided knowledge about epigenetic heredity, a process whereby genetic information can be preserved through modifications to chromatin without altering DNA nucleotide sequences. Future studies may be able to uncover the molecular mechanisms of histone modifiers, and further studies could perform screening of downstream genes by chromatin immunoprecipitation assays and microarrays to identify the specific target genes and their roles in cancer therapy. This may improve clinical outcomes or predict treatment outcomes for cancer patients.

\section{Acknowledgements}

The present study was supported by the National Basic Research Program of China (grant nos. 2012cb114603 and 2362015xk09), the National Natural Science Foundation of China (grant nos. 31501100 and 81201551), the Research Fund for the Doctoral Program of Higher Education of China (grant no. 20130182110003), the Fundamental Research Funds for the Central Universities (grant no. XDJK2013B020) and the Fundamental Research Funds for the Central University (grant no. XDJK2015C129).

\section{References}

1. Klener P: Epigenetic cancer drugs and their role in anticancer therapy. Vnitr Lek 59: 463-465, 2013 (In Czech).

2. Murray K: The occurrence of E-N-methyl lysine in histones. Biochemistry 3: 10-15, 1964

3. Yun M, Wu J, Workman JL and Li B: Readers of histone modifications. Cell Res 21: 564-578, 2011.

4. Biancotto $\mathrm{C}$, Frigè $\mathrm{G}$ and Minucci S: Histone modification therapy of cancer. Adv Genet 70: 341-386, 2010.

5. Kouzarides T: Chromatin modifications and their function. Cell 128: 693-705, 2007.

6. Lee JC, Kang SU, Jeon Y, Park JW, You JS, Ha SW, Bae N, Lubec G, Kwon SH, Lee JS, et al: Protein L-isoaspartyl methyltransferase regulates p53 activity. Nat Commun 3: 927, 2012.

7. Verma $M$ and Srivastava S: Epigenetics in cancer: Implications for early detection and prevention. Lancet Oncol 3: 755-763, 2002.

8. Chaib H, Prébet T, Vey N and Collette Y: Histone methyltransferases: A new class of therapeutic targets in cancer treatment? Med Sci (Paris) 27: 725-732, 2011 (In French).

9. Wang $X$ and Zhu WG: Advances in histone methyltransferases and histone demethylases. Ai Zheng 27: 1018-1025, 2008 (In Chinese).

10. Collazo E, Couture JF, Bulfer S and Trievel RC: A coupled fluorescent assay for histone methyltransferases. Anal Biochem 342 86-92, 2005.

11. Campagna-Slater V, Mok MW, Nguyen KT, Feher M, Najmanovich R and Schapira M: Structural chemistry of the histone methyltransferases cofactor binding site. J Chem Inf Model 51: 612-623, 2011.

12. Qian C and Zhou MM: SET domain protein lysine methyltransferases: Structure, specificity and catalysis. Cell Mol Life Sci 63 : 2755-2763, 2006.

13. Vermeulen M, Eberl HC, Matarese F, Marks H, Denissov S, Butter F, Lee KK, Olsen JV, Hyman AA, Stunnenberg HG, et al: Quantitative interaction proteomics and genome-wide profiling of epigenetic histone marks and their readers. Cell 142: 967-980, 2010.

14. Peterson CL and Laniel MA: Histones and histone modifications. Curr Biol 14: R546-R551, 2004.

15. Stancheva I: Caught in conspiracy: Cooperation between DNA methylation and histone H3K9 methylation in the establishment and maintenance of heterochromatin. Biochem Cell Biol 83: 385-395, 2005

16. Towbin BD, González-Aguilera C, Sack R, Gaidatzis D, Kalck V, Meister P, Askjaer P and Gasser SM: Step-wise methylation of histone $\mathrm{H} 3 \mathrm{~K} 9$ positions heterochromatin at the nuclear periphery. Cell 150: 934-947, 2012.
17. Krouwels IM, Wiesmeijer K, Abraham TE, Molenaar C, Verwoerd NP, Tanke HJ and Dirks RW: A glue for heterochromatin maintenance: Stable SUV39H1 binding to heterochromatin is reinforced by the SET domain. J Cell Biol 170: 537-549, 2005.

18. O'Carroll D, Scherthan H, Peters AH, Opravil S, Haynes AR, Laible G, Rea S, Schmid M, Lebersorger A, Jerratsch M, et al: Isolation and characterization of Suv39h2, a second histone H3 methyltransferase gene that displays testis-specific expression. Mol Cell Biol 20: 9423-9433, 2000.

19. Tachibana M, Sugimoto K, Fukushima T and Shinkai Y: Set domain-containing protein, G9a, is a novel lysine-preferring mammalian histone methyltransferase with hyperactivity and specific selectivity to lysines 9 and 27 of histone H3. J Biol Chem 276: 25309-25317, 2001

20. Tachibana M, Matsumura Y, Fukuda M, Kimura H and Shinkai Y: G9a/GLP complexes independently mediate H3K9 and DNA methylation to silence transcription. EMBO J 27: 2681-2690, 2008.

21. Li H, Rauch T, Chen ZX, Szabó PE, Riggs AD and Pfeifer GP: The histone methyltransferase SETDB1 and the DNA methyltransferase DNMT3A interact directly and localize to promoters silenced in cancer cells. J Biol Chem 281: 19489-19500, 2006.

22. Steele-Perkins G, Fang W, Yang XH, Van Gele M, Carling T, Gu J, Buyse IM, Fletcher JA, Liu J, Bronson R, et al: Tumor formation and inactivation of RIZ1, an Rb-binding member of a nuclear protein-methyltransferase superfamily. Genes Dev 15: 2250-2262, 2001

23. Falandry C, Fourel G, Galy V, Ristriani T, Horard B, Bensimon E, Salles G, Gilson E and Magdinier F: CLLD8/KMT1F is a lysine methyltransferase that is important for chromosome segregation. J Biol Chem 285: 20234-20241, 2010.

24. Ding J, Li T, Wang X, Zhao E, Choi JH, Yang L, Zha Y, Dong Z, Huang S, Asara JM, et al: The histone H3 methyltransferase G9A epigenetically activates the serine-glycine synthesis pathway to sustain cancer cell survival and proliferation. Cell Metab 18: 896-907, 2013.

25. Kondo Y, Shen L, Ahmed S, Boumber Y, Sekido Y, Haddad BR and Issa JP: Downregulation of histone H3 lysine 9 methyltransferase G9a induces centrosome disruption and chromosome instability in cancer cells. PLoS One 3: e2037, 2008.

26. Dong C, Wu Y, Yao J, Wang Y, Yu Y, Rychahou PG, Evers BM and Zhou BP: G9a interacts with Snail and is critical for Snail-mediated E-cadherin repression in human breast cancer. J Clin Invest 122: 1469-1486, 2012.

27. Chen MW, Hua KT, Kao HJ, Chi CC, Wei LH, Johansson G, Shiah SG, Chen PS, Jeng YM, Cheng TY, et al: H3K9 histone methyltransferase G9a promotes lung cancer invasion and metastasis by silencing the cell adhesion molecule Ep-CAM. Cancer Res 70: 7830-7840, 2010.

28. Hua KT, Wang MY, Chen MW, Wei LH, Chen CK, Ko CH, Jeng YM, Sung PL, Jan YH, Hsiao M, et al: The H3K9 methyltransferase G9a is a marker of aggressive ovarian cancer that promotes peritoneal metastasis. Mol Cancer 13: 189, 2014

29. Ke XX, Zhang D, Zhu S, Xia Q, Xiang Z and Cui H: Inhibition of H3K9 methyltransferase G9a repressed cell proliferation and induced autophagy in neuroblastoma cells. PLoS One 9: e106962, 2014.

30. Li KC, Hua KT, Lin YS, Su CY, Ko JY, Hsiao M, Kuo ML and Tan CT: Inhibition of G9a induces DUSP4-dependent autophagic cell death in head and neck squamous cell carcinoma. Mol Cancer 13: 172, 2014.

31. Yuan Y, Tang AJ, Castoreno AB, Kuo SY, Wang Q, Kuballa P, Xavier R, Shamji AF, Schreiber SL and Wagner BK: Gossypol and an HMT G9a inhibitor act in synergy to induce cell death in pancreatic cancer cells. Cell Death Dis 4: e690, 2013.

32. Son HJ, Kim JY, Hahn Y and Seo SB: Negative regulation of JAK2 by H3K9 methyltransferase G9a in leukemia. Mol Cell Biol 32: 3681-3694, 2012.

33. Lehnertz B, Pabst C, Su L, Miller M, Liu F, Yi L, Zhang R, Krosl J, Yung E, Kirschner J, et al: The methyltransferase G9a regulates HoxA9-dependent transcription in AML. Genes Dev 28: 317-327, 2014.

34. Tao H, Li H, Su Y, Feng D, Wang X, Zhang C, Ma H and $\mathrm{Hu}$ Q: Histone methyltransferase G9a and H3K9 dimethylation inhibit the self-renewal of glioma cancer stem cells. Mol Cell Biochem 394: 23-30, 2014.

35. Hung SY, Lin HH, Yeh KT and Chang JG: Histone-modifying genes as biomarkers in hepatocellular carcinoma. Int J Clin Exp Pathol 7: 2496-2507, 2014. 
36. Wu H, Zhang H, Wang P, Mao Z, Feng L, Wang Y, Liu C, Xia Q, Li B, Zhao H, et al: Short-Form CDYLb but not long-form CDYLa functions cooperatively with histone methyltransferase G9a in hepatocellular carcinomas. Genes Chromosomes Cancer 52: 644-655, 2013.

37. Zhong X, Chen X, Guan X, Zhang H, Ma Y, Zhang S, Wang E, Zhang L and Han Y: Overexpression of G9a and MCM7 in oesophageal squamous cell carcinoma is associated with poor prognosis. Histopathology 66: 192-200, 2015.

38. Schultz DC, Ayyanathan K, Negorev D, Maul GG and Rauscher FJ III: SETDB1: A novel KAP-1-associated histoneH3, lysine 9-specific methyltransferase that contributes to HP1-mediated silencing of euchromatic genes by KRAB zincfinger proteins. Genes Dev 16: 919-932, 2002.

39. Harte PJ, Wu W, Carrasquillo MM and Matera AG: Assignment of a novel bifurcated SET domain gene, SETDB1, to human chromosome band 1q21 by in situ hybridization and radiation hybrids. Cytogenet Cell Genet 84: 83-86, 1999.

40. Frietze S, O'Geen H, Blahnik KR, Jin VX and Farnham PJ: ZNF274 recruits the histone methyltransferase SETDB1 to the 3' ends of ZNF genes. PLoS One 5: e15082, 2010.

41. Cho S, Park JS and Kang YK: Dual functions of histone-lysine $\mathrm{N}$-methyltransferase Setdb1 protein at promyelocytic leukemianuclear body (PML-NB): Maintaining PML-NB structure and regulating the expression of its associated genes. J Biol Chem 286: 41115-41124, 2011.

42. Ceol CJ, Houvras Y, Jane-Valbuena J, Bilodeau S, Orlando DA, Battisti V, Fritsch L, Lin WM, Hollmann TJ, Ferré F, et al: The histone methyltransferase SETDB1 is recurrently amplified in melanoma and accelerates its onset. Nature 471: 513-517, 2011.

43. Lee JK and Kim KC: DZNep, inhibitor of S-adenosylhomocysteine hydrolase, down-regulates expression of SETDB1 H3K9me3 HMTase in human lung cancer cells. Biochem Biophys Res Commun 438: 647-652, 2013.

44. Rodriguez-Paredes M, Martinez de Paz A, Simó-Riudalbas L, Sayols S, Moutinho C,Moran S, Villanueva A, Vázquez-Cedeira M, Lazo PA, Carneiro F, et al: Gene amplification of the histone methyltransferase SETDB1 contributes to human lung tumorigenesis. Oncogene 33: 2807-2813, 2014.

45. Sun QY, Ding LW, Xiao JF, Chien W, Lim SL, Hattori N, Goodglick L, Chia D, Mah V, Alavi M, et al: SETDB1 accelerates tumourigenesis by regulating the WNT signalling pathway. J Pathol 235: 559-570, 2015.

46. Wu PC, Lu JW, Yang JY, Lin IH, Ou DL, Lin YH, Chou KH, Huang WF, Wang WP, Huang YL, et al: H3K9 histone methyltransferase, KMT1E/SETDB1, cooperates with the SMAD2/3 pathway to suppress lung cancer metastasis. Cancer Res 74: 7333-7343, 2014.

47. Spyropoulou A, Gargalionis A, Dalagiorgou G, Adamopoulos C, Papavassiliou KA, Lea RW, Piperi C and Papavassiliou AG: Role of histone lysine methyltransferases SUV39H1 and SETDB1 in gliomagenesis: Modulation of cell proliferation, migration, and colony formation. Neuromolecular Med 16: 70-82, 2014.

48. Sun Y, Wei M, Ren SC, Chen R, Xu WD, Wang FB, Lu J, Shen J, $\mathrm{Yu}$ YW, Hou JG, et al: Histone methyltransferase SETDB1 is required for prostate cancer cell proliferation, migration and invasion. Asian J Androl 16: 319-324, 2014.

49. Zhang H, Cai K, Wang J, Wang X, Cheng K, Shi F, Jiang L, Zhang Y and Dou J: MiR-7, inhibited indirectly by lincRNA HOTAIR, directly inhibits SETDB1 and reverses the EMT of breast cancer stem cells by downregulating the STAT3 pathway. Stem Cells 32: 2858-2868, 2014

50. Kouzarides T: Histone methylation in transcriptional control Curr Opin Genet Dev 12: 198-209, 2002.

51. Jansen MP, Reijm EA, Sieuwerts AM, Ruigrok-Ritstier K, Look MP, Rodríguez-González FG, Heine AA, Martens JW, Sleijfer S, Foekens JA, et al: High miR-26a and low CDC2 levels associate with decreased EZH2 expression and with favorable outcome on tamoxifen in metastatic breast cancer. Breast Cancer Res Treat 133: 937-947, 2012.

52. Raaphorst FM, Meijer CJ, Fieret E, Blokzijl T, Mommers E, Buerger H, Packeisen J, Sewalt RA, Otte AP and van Diest PJ: Poorly differentiated breast carcinoma is associated with increased expression of the human polycomb group EZH2 gene. Neoplasia 5: 481-488, 2003.

53. Mu Z, Li H, Fernandez SV, Alpaugh KR, Zhang R and Cristofanilli M: EZH2 knockdown suppresses the growth and invasion of human inflammatory breast cancer cells. J Exp Clin Cancer Res 32: 70, 2013.

54. Zeidler M, Varambally S, Cao Q, Chinnaiyan AM, Ferguson DO, Merajver SD and Kleer CG: The Polycomb group protein EZH2 impairs DNA repair in breast epithelial cells. Neoplasia 7: 1011-1019, 2005.
55. Hoffmann MJ, Engers R, Florl AR, Otte AP, Muller M and Schulz WA: Expression changes in EZH2, but not in BMI-1, SIRT1, DNMT1 or DNMT3B are associated with DNA methylation changes in prostate cancer. Cancer Biol Ther 6: 1403-1412, 2007

56. Varambally S, Dhanasekaran SM, Zhou M, Barrette TR, Kumar-Sinha C, Sanda MG, Ghosh D, Pienta KJ, Sewalt RG, Otte AP, et al: The polycomb group protein EZH2 is involved in progression of prostate cancer. Nature 419: 624-629, 2002.

57. Bryant RJ, Cross NA, Eaton CL, Hamdy FC and Cunliffe VT: $\mathrm{EZH} 2$ promotes proliferation and invasiveness of prostate cancer cells. Prostate 67: 547-556, 2007.

58. Kim SH, Joshi K, Ezhilarasan R, Myers TR, Siu J, Gu C, Nakano-Okuno M, Taylor D, Minata M, Sulman EP, et al: EZH2 protects glioma stem cells from radiation-induced cell death in a MELK/FOXM1-dependent manner. Stem Cell Rep 4 : 226-238, 2015.

59. Zhang W, Lv S, Liu J, Zang Z, Yin J, An N, Yang H and Song Y: PCI-24781 down-regulates EZH2 expression and then promotes glioma apoptosis by suppressing the PIK3K/Akt/mTOR pathway. Genet Mol Biol 37: 716-724, 2014.

60. Xu ZQ, Zhang L, Gao BS, Wan YG, Zhang XH, Chen B, Wang YT, Sun N and Fu YW: EZH2 promotes tumor progression by increasing VEGF expression in clear cell renal cell carcinoma. Clin Transl Oncol 17: 41-49, 2015.

61. Xia H, Zhang W, Li Y, Guo N and Yu C: EZH2 silencing with RNA interference induces $\mathrm{G}_{2} / \mathrm{M}$ arrest in human lung cancer cells in vitro. BioMed Res Int 2014: 348728, 2014.

62. Guo SQ and Zhang YZ: Overexpression of enhancer of zests homolog 2 in lymphoma. Chin Med J (Engl) 125: 3735-3739, 2012.

63. Fujii S, Ito K, Ito $\mathrm{Y}$ and Ochiai A: Enhancer of zeste homologue 2 (EZH2) down-regulates RUNX3 by increasing histone H3 methylation. J Biol Chem 283: 17324-17332, 2008.

64. Zhang P, Yang X, Ma X, Ingram DR, Lazar AJ, Torres KE and Pollock RE: Antitumor effects of pharmacological EZH2 inhibition on malignant peripheral nerve sheath tumor through the miR-30a and KPNB1 pathway. Mol Cancer 14: 55, 2015.

65. Dubuc AM, Remke M, Korshunov A, Northcott PA, Zhan SH, Mendez-Lago M, Kool M, Jones DT, Unterberger A, Morrissy AS, et al: Aberrant patterns of $\mathrm{H} 3 \mathrm{~K} 4$ and $\mathrm{H} 3 \mathrm{~K} 27$ histone lysine methylation occur across subgroups in medulloblastoma. Acta Neuropathol 125: 373-384, 2013.

66. Wan J, Zhan J, Li S, Ma J, Xu W, Liu C, Xue X, Xie Y, Fang W, Chin YE, et al: PCAF-primed EZH2 acetylation regulates its stability and promotes lung adenocarcinoma progression. Nucleic Acids Res 43: 3591-3604, 2015.

67. Pekowska A, Benoukraf T, Zacarias-Cabeza J, Belhocine M, Koch F, Holota H, Imbert J, Andrau JC, Ferrier P and Spicuglia S: $\mathrm{H} 3 \mathrm{~K} 4$ tri-methylation provides an epigenetic signature of active enhancers. EMBO J 30: 4198-4210, 2011.

68. Wang P, Lin C, Smith ER, Guo H, Sanderson BW, Wu M, Gogol M, Alexander T, Seidel C, Wiedemann LM, et al: Global analysis of $\mathrm{H} 3 \mathrm{~K} 4$ methylation defines MLL family member targets and points to a role for MLL1-mediated H3K4 methylation in the regulation of transcriptional initiation by RNA polymerase II. Mol Cell Biol 29: 6074-6085, 2009.

69. Wu M, Wang PF, Lee JS, Martin-Brown S, Florens L, Washburn M and Shilatifard A: Molecular regulation of $\mathrm{H} 3 \mathrm{~K} 4$ trimethylation by Wdr82, a component of human Set1/COMPASS. Mol Cell Biol 28: 7337-7344, 2008

70. Gregory GD, Vakoc CR, Rozovskaia T, Zheng X, Patel S, Nakamura T, Canaani E and Blobel GA: Mammalian ASH1L is a histone methyltransferase that occupies the transcribed region of active genes. Mol Cell Biol 27: 8466-8479, 2007.

71. Stoller JZ, Huang L, Tan CC, Huang F, Zhou DD, Yang J, Gelb BD and Epstein JA: Ash2l interacts with Tbx1 and is required during early embryogenesis. Exp Biol Med (Maywood) 235: 569-576, 2010.

72. Hamamoto R, Furukawa Y, Morita M, Iimura Y, Silva FP, Li M, Yagyu R and Nakamura Y: SMYD3 encodes a histone methyltransferase involved in the proliferation of cancer cells. Nat Cell Biol 6: 731-740, 2004.

73. Tao Y, Neppl RL, Huang ZP, Chen J, Tang RH, Cao R, Zhang Y, Jin SW and Wang DZ: The histone methyltransferase Set $7 / 9$ promotes myoblast differentiation and myofibril assembly. J Cell Biol 194: 551-565, 2011.

74. Sirinupong N, Brunzelle J, Ye J, Pirzada A, Nico L and Yang Z: Crystal structure of cardiac-specific histone methyltransferase SmyD1 reveals unusual active site architecture. J Biol Chem 285: 40635-40644, 2010 
75. Peserico A, Germani A, Sanese P, Barbosa AJ, di Virgilio V, Fittipaldi R, Fabini E, Bertucci C, Varchi G, Moyer MP, et al: A SMYD3 small-molecule inhibitor impairing cancer cell growth. J Cell Physiol 230: 2447-2460, 2015.

76. Xu JY, Chen LB, Xu JY, Yang Z, Wei HY and Xu RH: Inhibition of SMYD3 gene expression by RNA interference induces apoptosis in human hepatocellular carcinoma cell line HepG2 Ai Zheng 25: 526-532, 2006 (In Chinese).

77. Dong SW, Zhang H, Wang BL, Sun P, Wang YG and Zhang P Effect of the downregulation of SMYD3 expression by RNA $\mathrm{i}$ on RIZ1 expression and proliferation of esophageal squamous cell carcinoma. Oncol Rep 32: 1064-1070, 2014.

78. Hamamoto R, Silva FP, Tsuge M, Nishidate T, Katagiri T, Nakamura Y and Furukawa Y: Enhanced SMYD3 expression is essential for the growth of breast cancer cells. Cancer Sci 97 113-118, 2006

79. Wang SZ, Luo XG, Shen J, Zou JN, Lu YH and Xi T: Knockdown of SMYD3 by RNA interference inhibits cervical carcinoma cell growth and invasion in vitro. BMB Rep 41: 294-299, 2008.

80. Liu C, Wang C, Wang K, Liu L, Shen Q, Yan K, Sun X, Chen J, Liu J, Ren H, et al: SMYD3 as an oncogenic driver in prostate cancer by stimulation of androgen receptor transcription. J Nat Cancer Inst 105: 1719-1728, 2013.

81. Morishita M and di Luccio E: Cancers and the NSD family of histone lysine methyltransferases. Biochim Biophys Acta 1816 158-163, 2011

82.Duns G, van den Berg E, van Duivenbode I, Osinga J, Hollema H, Hofstra RM and Kok K: Histone methyltransferase gene SETD2 is a novel tumor suppressor gene in clear cell renal cell carcinoma. Cancer Res 70: 4287-4291, 2010.

83. Maltby VE, Martin BJ, Schulze JM, Johnson I, Hentrich T, Sharma A, Kobor MS and Howe L: Histone H3 lysine 36 methylation targets the Iswlb remodeling complex to chromatin. Mol Cell Biol 32: 3479-3485, 2012

84. Sampson ER, Yeh SY, Chang HC, Tsai MY, Wang X, Ting HJ and Chang C: Identification and characterization of androgen receptor associated coregulators in prostate cancer cells. J Biol Regul Homeost Agents 15: 123-129, 2001.

85. Bianco-Miotto T, Chiam K, Buchanan G, Jindal S, Day TK, Thomas M, Pickering MA, O'Loughlin MA, Ryan NK, Raymond WA, et al: Global levels of specific histone modifications and an epigenetic gene signature predict prostate cancer progression and development. Cancer Epidemiol Biomarkers Prev 19: 2611-2622, 2010.

86. Berdasco M, Ropero S, Setien F, Fraga MF, Lapunzina $P$, Losson R, Alaminos M, Cheung NK, Rahman N and Esteller M: Epigenetic inactivation of the Sotos overgrowth syndrome gene histone methyltransferase NSD1 in human neuroblastoma and glioma. Proc Natl Acad Sci USA 106: 21830-21835, 2009.

87.Zhao F, Chen Y, Zeng L, Li R, Zeng R, Wen L, Liu Y and Zhang C: Role of triptolide in cell proliferation, cell cycle arrest, apoptosis and histone methylation in multiple myeloma U266 cells. Eur J Pharmacol 646: 1-11, 2010.

88. Thanasopoulou A, Tzankov A and Schwaller J: Potent co-operation between the NUP98-NSD1 fusion and the FLT3-ITD mutation in acute myeloid leukemia induction. Haematologica 99: 1465-1471, 2014.

89. Ostronoff F, Othus M, Gerbing RB, Loken MR, Raimondi SC, HirschBA,LangeBJ,PetersdorfS,RadichJ,AppelbaumFR, etal NUP98/NSD1 and FLT3/ITD coexpression is more prevalent in younger AML patients and leads to induction failure: A COG and SWOG report. Blood 124: 2400-2407, 2014.

90. Job B, Bernheim A, Beau-Faller M, Camilleri-Broët S, Girard P, Hofman P, Mazières J, Toujani S, Lacroix L, Laffaire J, et al; LG Investigators: Genomic aberrations in lung adenocarcinoma in never smokers. PLoS One 5: e15145, 2010.

91. Seiwert TY, Zuo Z, Keck MK, Khattri A, Pedamallu CS, Stricker T, Brown C, Pugh TJ, Stojanov P, Cho J, et al: Integrative and comparative genomic analysis of HPV-positive and HPV-negative head and neck squamous cell carcinomas. Clin Cancer Res 21: 632-641, 2015.
92. Deardorff MA, Maisenbacher M and Zackai EH: Ganglioglioma in a Sotos syndrome patient with an NSD1 deletion. Am J Med Genet A 130A: 393-394, 2004

93. Wang Y, Thomas A, Lau C, Rajan A, Zhu Y, Killian JK, Petrini I, Pham T, Morrow B, Zhong X, et al: Mutations of epigenetic regulatory genes are common in thymic carcinomas. Sci Rep 4: 7336, 2014

94. Gossage L, Murtaza M, Slatter AF, Lichtenstein CP, Warren A, Haynes B, Marass F, Roberts I, Shanahan SJ, Claas A, et al: Clinical and pathological impact of VHL, PBRM1, BAP1, SETD2, KDM6A, and JARID1c in clear cell renal cell carcinoma. Genes Chromosomes Cancer 53: 38-51, 2014.

95. Hao C, Wang L, Peng S, Cao M, Li H, Hu J, Huang X, Liu W, Zhang $\mathrm{H}, \mathrm{Wu} \mathrm{S}$, et al: Gene mutations in primary tumors and corresponding patient-derived xenografts derived from non-small cell lung cancer. Cancer Lett 357: 179-185, 2015.

96. Huether R, Dong L, Chen X, Wu G, Parker M, Wei L, Ma J, Edmonson MN, Hedlund EK, Rusch MC, et al: The landscape of somatic mutations in epigenetic regulators across 1,000 paediatric cancer genomes. Nat Commun 5: 3630, 2014.

97. Zhang Q, Xue P, Li H, Bao Y, Wu L, Chang S, Niu B, Yang F and Zhang T: Histone modification mapping in human brain reveals aberrant expression of histone $\mathrm{H} 3$ lysine 79 dimethylation in neural tube defects. Neurobiol Dis 54: 404-413, 2013.

98. Martin $\mathrm{C}$ and Zhang Y: The diverse functions of histone lysine methylation. Nat Rev Mol Cell Biol 6: 838-849, 2005.

99. Kim W, Choi M and Kim JE: The histone methyltransferase Dot1/DOT1L as a critical regulator of the cell cycle. Cell Cycle 13: 726-738, 2014

100. Chang MJ, Wu H, Achille NJ, Reisenauer MR, Chou CW, Zeleznik-Le NJ, Hemenway CS and Zhang W: Histone H3 lysine 79 methyltransferase Dot1 is required for immortalization by MLL oncogenes. Cancer Res 70: 10234-10242, 2010.

101. Kim W, Kim R, Park G, Park JW and Kim JE: Deficiency of H3K79 histone methyltransferase Dot1-like protein (DOT1L) inhibits cell proliferation. J Biol Chem 287: 5588-5599, 2012.

102. Oda H, Okamoto I, Murphy N, Chu J, Price SM, Shen MM, Torres-Padilla ME, Heard E and Reinberg D: Monomethylation of histone H4-lysine 20 is involved in chromosome structure and stability and is essential for mouse development. Mol Cell Biol 29: 2278-2295, 2009.

103. Qin Y, Ouyang H, Liu J and Xie Y: Proteome identification of proteins interacting with histone methyltransferase SET8. Acta Biochim Biophys Sin, Shanghai, 2013.

104. Jørgensen S, Schotta G and Sørensen CS: Histone H4 lysine 20 methylation: Key player in epigenetic regulation of genomic integrity. Nucleic Acids Res 41: 2797-2806, 2013.

105. Wu S and Rice JC: A new regulator of the cell cycle: The PR-Set7 histone methyltransferase. Cell Cycle 10: 68-72, 2011.

106. Morishita M and di Luccio E: Structural insights into the regulation and the recognition of histone marks by the SET domain of NSD1. Biochem Biophys Res Commun 412: 214-219, 2011.

107. Yang P, Guo L, Duan ZJ, Tepper CG, Xue L, Chen X, Kung HJ, Gao AC, Zou JX and Chen HW: Histone methyltransferase NSD2/MMSET mediates constitutive NF- $\kappa \mathrm{B}$ signaling for cancer cell proliferation, survival, and tumor growth via a feedforward loop. Mol Cell Biol 32: 3121-3131, 2012.

108. Beck DB, Oda H, Shen SS and Reinberg D: PR-Set7 and H4K20me1: At the crossroads of genome integrity, cell cycle, chromosome condensation, and transcription. Genes Dev 26: 325-337, 2012.

109. Yokoyama Y, Matsumoto A, Hieda M, Shinchi Y, Ogihara E, Hamada M, Nishioka Y, Kimura H, Yoshidome K, Tsujimoto M, et al: Loss of histone H4K20 trimethylation predicts poor prognosis in breast cancer and is associated with invasive activity. Breast Cancer Res 16: R66, 2014. 